\author{
Anjan Mitra, Saptarshi Mitra
}

\title{
Responsible Design Practice for Collective Living
}

\author{
Práctica del Diseño Responsable para la Vida \\ Colectiva
}

Prática de Desenho Responsável para uma Vida
Colectiva

Abstract $\mid$ Resumen | Resumo

The Covid-19 pandemic is a cusp, a critical juncture which has brought into the foreground the inadequacies of our present development agendas, spatial practices and their manifestations. It is here and now that we, as professionals, need to question our roles and activities, moving forward to take ownership of our own practice, take cognisance of this call for change and reorient our philosophies, our strategies and our work to a more grounded, passionate and humane approach. Based on research into pre-industrial spatial practices and experiences of several of our projects, we seek a new paradigm - one that we call "Responsible Design Practice”.

La pandemia de Covid-19 es una antesala, una coyuntura crítica que ha puesto en primer plano las insuficiencias de nuestras agendas actuales de desarrollo, sus prácticas espaciales y sus manifestaciones. Es aquí y ahora cuando nosotros, como profesionales, necesitamos cuestionar nuestros roles y actividades, avanzar hacia la toma de control de nuestro propio ejercicio profesional, concienciarnos de esta llamada al cambio y reorientar nuestras filosofías, estrategias y trabajo hacia un enfoque más fundamentado, apasionado y humano. Basándonos en la investigación de las prácticas espaciales preindustriales y las experiencias de varios de nuestros proyectos, buscamos un nuevo paradigma, uno al que hemos denominado "Práctica del Diseño Responsable”.

A pandemia Covid-19 é uma cúspide, um momento decisivo que trouxe para o primeiro plano as insuficiências dos nossos actuais planos de desenvolvimento e práticas espaciais e das suas manifestações. É aqui e agora que nós, como profissionais, precisamos de questionar os nossos papéis e actividades, avançando no sentido de nos apropriarmos da nossa própria prática, e tomar conhecimento deste apelo à mudança e reorientar as nossas filosofias, as nossas estratégias e o nosso trabalho para uma abordagem mais enraizada, empenhada e humana. Com base na investigação das práticas espaciais pré-industriais e na experiência com os nossos vários projectos, procuramos um novo paradigma para o envolvimento, um paradigma a que chamamos "Prática de Desenho Responsável". 


\section{Introduction}

After the Covid-19 crisis, the world is a different place. The way we live, engage with our surroundings, our social life or even the way we think have been challenged at different levels. This scenario has forced us to question our lifestyles, our adopted values, development agendas, goals, and planning policies. It has led us to question our very existence and humanity.

"Social distancing" has become the norm today, revealing the deep fissures and differences within society.This situation has also made clearer some of the fallacies of our current structures and practices - those which are propagated by global corporations through extensive exploitation of resources and energy to create standardised products fit for mass consumption. It has also highlighted our fragile, self-serving development agendas based on extraction of materials, exploitation of labour, consumerism and accumulation and capitalisation of wealth, promoting intense competition for success and thereby eroding identities, shared values, ideas of collaboration and co-production. This process has concentrated power to a privileged few while condemning the vast majority to almost inhuman existences. These dominant structures and practices have, over time, popularised certain traits in our built environment, including spatial characteristics, land use patterns and infrastructure. Covid-19 has highlighted the incompatibility of these traits with nature, the environment, and the ecosystem. It is architects, designers and planners who have implemented these development policies. As such, we have been acting without being conscious of our responsibility to society, nature and the environment in a sustained manner.

But Covid-19 can also be understood as nature's reaction - a necessary warning that the present development paradigm needs serious reconsideration and a search for a more sustainable alternative. It becomes important to question our roles, the part we have played - as designers, architects, or builders - in propagating this development paradigm. Moving forward, it is our responsibility to be aware of this call for change and reorient our philosophies, our strategies, and our practices from a technology-centred, energy-intensive stance to a more grounded, passionate and humane approach. "If you want the change, be the change". This is a much-repeated thought which needs to be put into practice.

In framing a future set of ethic principles and strategies, our research into our pre-industrial knowledge has been essential, and this can be studied through our built heritage and our traditional cultural and spatial practices. The approach for this kind of analysis must be collective, not individual, focused on collective sustainability, collective resilience and collective wellbeing. This research into the pre-industrial scenario must be developed mainly in two domains: Traditional Buildings and Building Traditions.

\section{Traditional Buildings}

Traditional buildings, especially those which are public buildings, have been designed and executed by highly specialised guilds, embodying the highest levels of art, culture, crafts, and philosophical awareness of a particular society at a point in time. These buildings represent particular cultural practices, physical manifestations of particular communities, their shared values, and their social and cultural norms.

Numerous types of temple as well as other sacred, social or public institutions belong to this category. Most of these buildings communicate a collective ethos, traditions, and beliefs. In India, they have been historically conceived by the sthapatis. In Europe and other regions, by the various guilds of builders. Therefore, a study of traditional buildings is a study of a repository of human passion, emotion and social and cultural connections; not only of their visual manifestations and style. 


\section{Building Traditions}

Building traditions are a set of practices that address highly contextual cultural, spatial, and material specificities. Every culture has developed an acquired knowledge of cultural behaviour and social norms, fine tuning its response and dependence with nature, the ecosystem and the environment. These practices are expressed as tangible manifestations, but at the same time, they are the anchors of intangible expressions - art, cuisine, dress, music, festivals, events, crafts, etc. Building traditions evolve through a people-centric, collaborative process. The process of accumulation and fine-tuning of traditions occurs in a majorly informal, adaptable, socially rooted and negotiated way.

Building traditions therefore generate built forms based on shared design principles and contextual knowledge; forms linked to each community. There is a very rich social content in these forms of architecture. The collective shared ideas prevail in the final expression.

On the contrary, modernist architecture in all its forms mainly relies on the "self". The individual (designer, builder, owner, developer, promoter) is of utmost importance. Built forms become a final product in themselves. Everything local and everything shared (pride, heritage, context, culture, and society) is discarded in the process.

\section{A new paradigm in Architecture}

The role of Architecture must be redefined. It can be turned into a socially engaged, critical and contextual profession. We must work out a middle ground and change how we think. A paradigm shift is required. This is an opportunity to seek and implement new development strategies and design ideas to restore balance in the current Humanity-Nature conflict. This new approach must rely on traditional wisdom and shared knowledge and building practices while meeting contemporary requirements. Local skills and resources must be acknowledged, as well as their collaborative potential. Finally, future design practice and practitioners must be made responsible and accountable for their actions, ideas and impacts on society, the environment and the ecosystem.

This necessary new paradigm, which we term "Responsible Design Practice", must reject unilateral technological dependence and intensive energy use and balance the gains and profits for the individual in favour of collective improvement. Technological knowhow and innovation must become a support mechanism to enable and guide, rather than dictate. Sustainability is an essential prerequisite and a major factor for negotiating the options and choices of design interventions. We must build on existing assets (materials, skills, heritage, etc.) to reframe the development agenda. The continuity of local knowledge, memory, traditions and values is instrumental to that aim.

This approach helped us to negotiate development issues in our own practice. Two implemented projects are presented here as examples to demonstrate its viability. They show how highimpact, high-energy consumption and extractive intervention strategies can be replaced by an appropriate, meaningful engagement.

\section{Restoration of the Pancharathnam Temple at Garh Panchakot, Puruliya district, West Bengal}

The Pancharathnam Temple at Garh Panchakot is a good example of traditional Bengal temple architecture of from the $16^{\text {th }}$ and $17^{\text {th }}$ centuries. It is a brick temple with detailed cultural narratives carved into the numerous terracotta embellishments. The temple used to be an important sacred space nurtured by the Panchakot kingdom as part of their capital complex. It is now part of a cluster of archaeological ruins in the foothills of Panchet. The West Bengal Heritage Commission identified this temple as an important element in the cultural landscape of Puruliya.

The temple is an elaborate two-storey architectural composition, inspired by and transformed from the local chala form (roof form), following the local building tradition. The structure adapted Islamic 
Diverse traditional building crafts during the restoration works of Pancharathnam Temple at Garh Panchakot, West Bengal

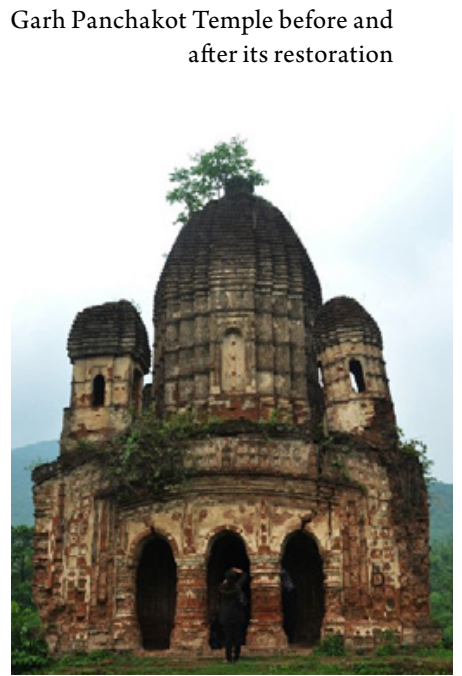

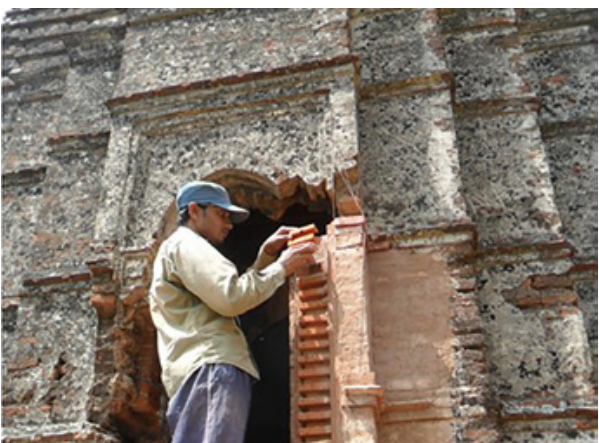
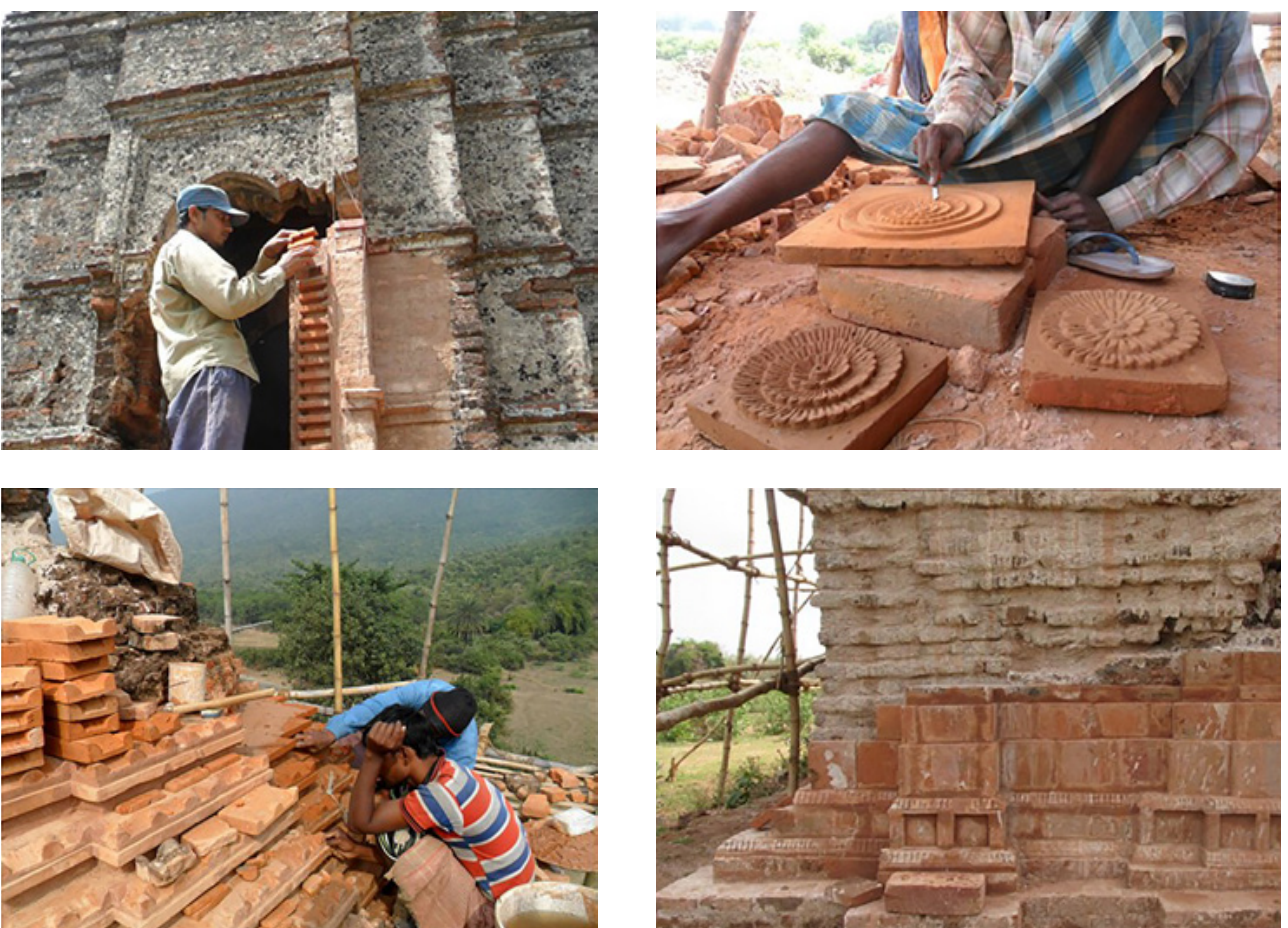

traditions of building vaults and arches and also incorporated a Nagara type of shikhara (towerlike spire) in ratna (jewel) form. It is a pancharatna (five ratnas) design, with a typical square plan, four ratnas in the corners and a two-storey shikhara in the centre. The temple was abandoned after its principal deity was relocated by one of the kings to his new capital. This disconnected it from the community and eventually the building fell into disrepair which led to its partial collapse.

We had documented the temple in 2014, but the restoration works started in 2017 and finished in 2018.

Following the "Responsible Design Practice" principle, our restoration project relied on local building traditions and supported their revival. We adopted a traditional set of materials and gave continuity to the existing building techniques. Lime-based mortar with surkhi (chamotte), which has been historically prevalent in this region, was used. The bricks were reused when suitable

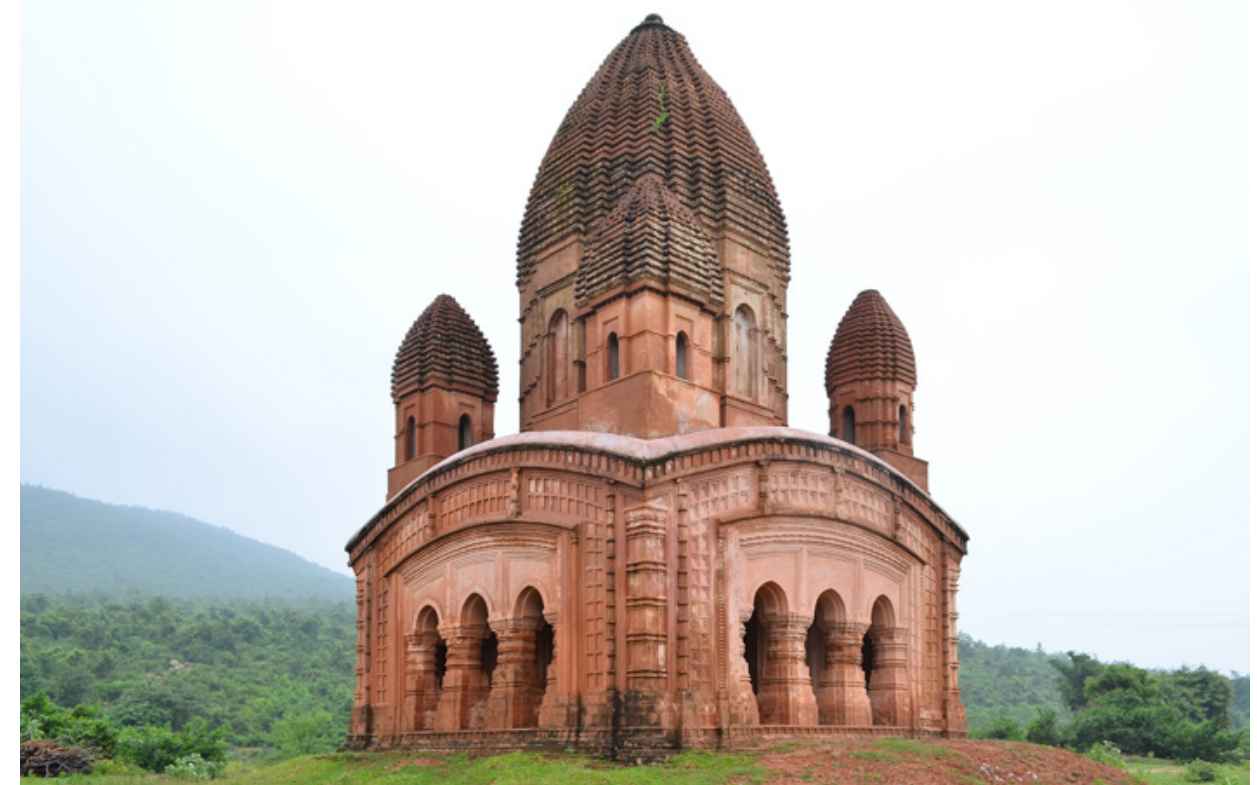


and similar ones were produced in the local kiln. Local craftspeople and masons were engaged and monitored by the local community. However, in the terracotta work only floral motifs were replicated, while leaving the cultural narratives as they were found to avoid losing the patina of time.

Furthermore, to really conserve the structure, it was argued that the sacred space should be revived by reinstalling the local deity, initiating the prevalent rituals and creating a scenario where the local community once more uses this space, interacts with it and thus brings it to life.

This project has finally triggered a more holistic approach to revive the cultural landscape of the Garh Panchakot capital complex. There is now renewed interest in the region in the various historic structures still preserved - fort walls, temples, palace and numerous water tanks and ecological features. This project started a process through which a community has been reinvigorated through architecture.

\section{Mon Chasha, Paoshi, West Bengal}

"Responsible Design Practice" can guide not just our restoration work, but also the development of new buildings. Mon Chasha, near Kolkata, also in India, is a good example of this.

Mon Chasha is a community-based rural tourism (CBRT) initiative. The project was inspired by the Incredible India campaign, developed by the United Nations Development Programme along with the Government of India. It was carried out as a collaboration between a local facilitator/NGO and an architectural design team. An orphanage, Antodaya Ashram, operated in Paoshi village with about sixty boys and girls. They were in a constant crisis for raising the funds necessary to sustain their daily operations. Mon Chasha was created to support the ashram by installing CBRT facilities in the adjoining land. This place would focus on providing an authentic experience of rural Bengal, of its life and ethos. The concept was developed as a reinterpretation of local building traditions and cultural wisdom. The entire planning and design process of this cultural hub was conceived on-site, together with local craftspeople. The decision was made to source all materials and labour required for this project from the locality itself and to draw on local knowledge for the construction. The design was inspired by the chang typology from the Brahmaputra flood plains of Assam. Bamboo and coconut planks were the main structural elements. Walls, floors, doors, windows and furniture were fabricated out of bamboo by the local craftspeople. Hogla thatch, made from a local plant, was used to create the roof. Mud, another popular local building material, was extensively used in the project for sculpting ovens and shaping walls, niches and porches.

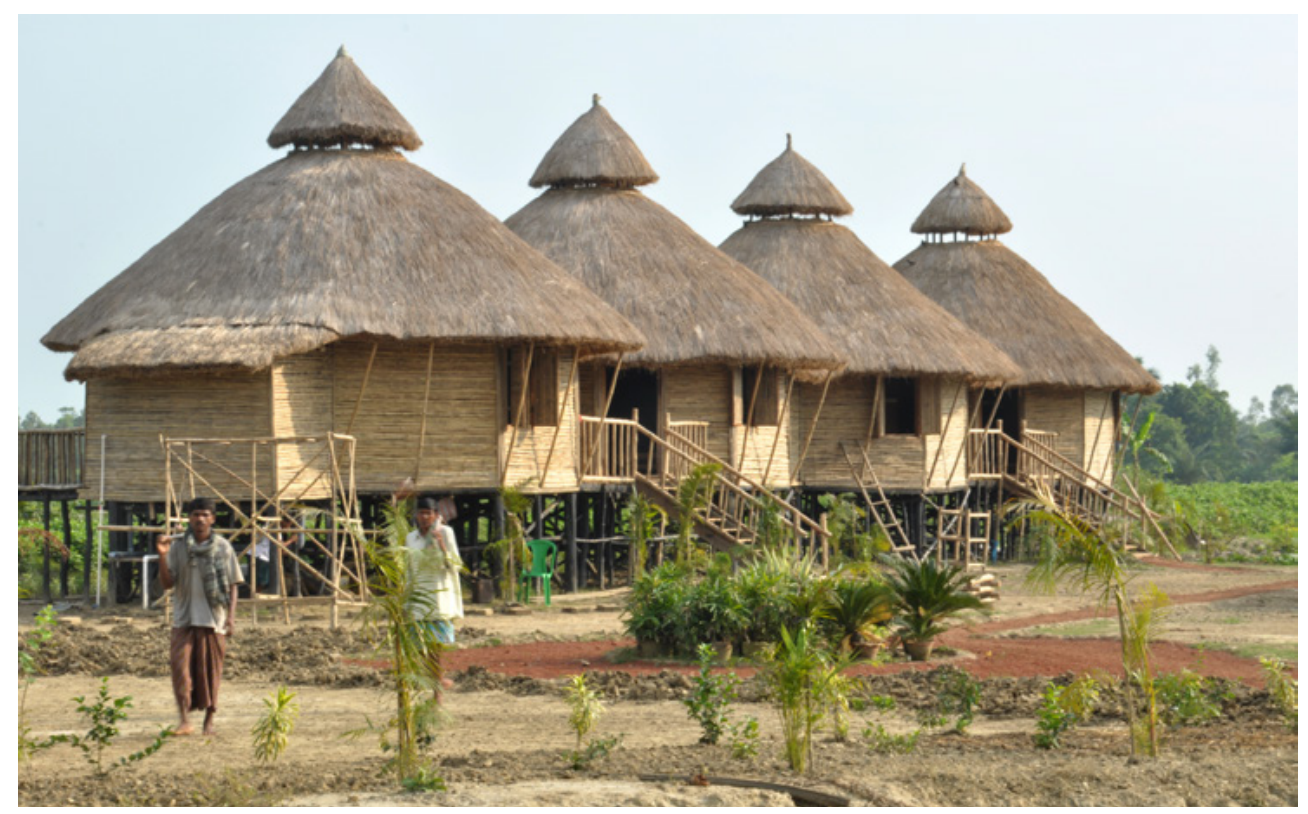



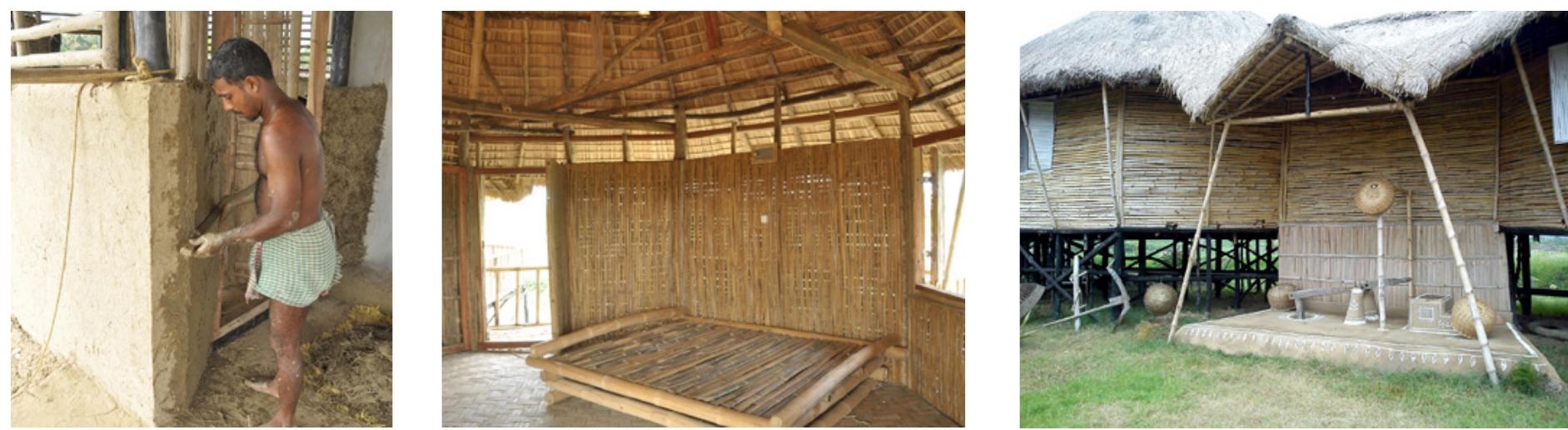

Traditional crafts applied to the construction

The project also needed to meet high standards of hygiene and waste management. For this purpose, modern toilets were installed, along with a grey water management system. Vermicomposting, pisciculture and organic farming was incorporated on the site. The local village sacred narratives and folk traditions have, over time, become part of the campus too. As a result, Mon Chasha evolved into a place that is extremely rooted not just to the traditions of building, but also to its wider cultural context. It has therefore achieved a strong connection with the community and its culture, as well as with the landscape. The project has provided a tangible framework to nurture intangible expressions: the cuisine, beliefs, rituals, values and lifestyles that provide the visitors with an authentic experience of Rural Bengal. Mon Chasha has become one of the six most popular tourist destinations of West Bengal and a sustained source of support for the ever-expanding activities of the Antodaya Ashram.

\section{Conclusion}

As illustrated through these two projects, Responsible Design Practice can bring about an essential paradigm shift, allowing us to relearn important tenets from our past and couple them innovatively with our modern knowhow. This shift to a larger and collective set of values is an urgent necessity. We must recalibrate the set of core ethical principles, tools and methodologies that we use. Ultimately, we, as a collective of design professionals, have to take responsibility, support society, and equip it with the necessary means to construct a more resilient and sustainable future.

\section{Biographies | Biografías | Biografias}

\section{Anjan Mitra}

$\mathrm{He}$ is interested in the social relevance of Design and Architecture. His search for Responsible Architecture in the Indian context began in 1992 through his firm The Appropriate Alternative, where he has worked in and explored various materials, practices, and contexts. Notable examples of his work are the MonChasha - a community-based rural tourism project, the restoration of the Pancharatna temple in Purulia, or the adaptive reuse of an old Chinatown tannery building for iLEAD Kolkata. He is extensively engaged in teaching and research and is an active member of INTACH, IUDI and other professional bodies. His authored research projects include "Euro-Indian urbanism on the banks of the Ganges”, “Understanding slums as urban systems” and Kolkata o Durgapujo (Ananda Publishers, 2015). He is a cofounder of SAVE (Sustained Actions for Value and Environment) interdisciplinary think-tank.

\section{Saptarshi Mitra}

He has a background in Architecture and Development Practice and has lived and worked in India, Spain, the United Kingdom and Myanmar. He has worked on a variety of projects, ranging from Architecture and Urban Design to Conservation, Community-based Tourism and Community-led development. At the same time, he has been a part of academia and has led various workshops ranging from the documentation of heritage sites to the exploration of materials and technology. He believes that design can be understood as a way of adding value - a collective exercise that at its core revolves around maximising the potentials of space, culture and context to create better conditions for everyday life. He is also a strong believer in the necessity and capacity of people to lead the change they want to see, bringing perspectives of participation, co-production and collaboration to The Appropriate Alternative, Disappearing Dialogues and SAVE (Sustained Actions for Value and Environment). 